DOI: $10.4172 / 2471-8416.100023$

\title{
Amniotic Membrane: Innovative Use in the Coverage of Severe Injury
}

\author{
Gabriela Martínez, Cecilia Menéndez, Santiago Alemann and Bibiana Dello Russo*
}

Department of Orthopedics and Traumatology, J. P. Garrahan, Pediatric Hospital, Buenos Aires, Argentina

*Corresponding author: Bibiana Dello Russo, Department of Orthopedics and Traumatology, J. P. Garrahan, Pediatric Hospital, Buenos Aires, Argentina, Tel: 1148078058; E-mail: bibianadellorusso@yahoo.com.ar

Received date: June 23, 2016; Accepted date: August 08, 2016; Published date: August 11, 2016

Citation: Martínez G, Menéndez C, Alemann S, Dello Russo B (2016) Amniotic Membrane: Innovative use in the Coverage of Severe Injury. J Clin Exp Orthop 2: 23. doi: 10.4172/2471-8416.100023

Copyright: (C 2016 Martínez G, et al. This is an open-access article distributed under the terms of the Creative Commons Attribution License, which permits unrestricted use, distribution, and reproduction in any medium, provided the original author and source are credited.

\section{Introduction}

In severe wounds in which primary closure is not feasible, intervention with alternative coverage is warranted. Success will depend on bed revascularization, graft take, and immobilization in the wound bed. Adherence may be hindered in different anatomical locations, such as limbs or back, leading to graft loss. Several methods have been described for fixation.

\section{Case Report}

We report the case of a pediatric multiple-trauma patient with an exposed pelvis wound and extensive fractures in the dorsolumbar region.

\section{Clinical Case}

A 9-year-old patient was referred to our center because of a pelvic fracture type $\mathrm{C} 2$ according to the Tile classification, also called a Morel-Lavallee lesion: a closed degloving soft tissue injury caused by the abrupt separation of the skin and subcutaneous tissue from the muscle fascia, creating a space filled with blood, lymphatic fluid, and liquified fat (Figures 1).

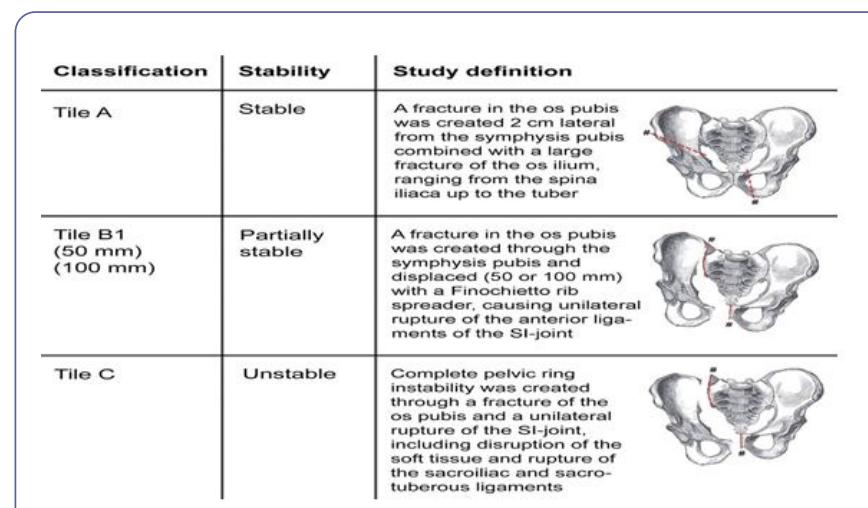

Figure 1: Tile classification for pelvic fracture.

Morel-Lavallee lesions are common in patients with acetabular and pelvic fractures secondary to high-energy trauma (Figures 2 and 3).

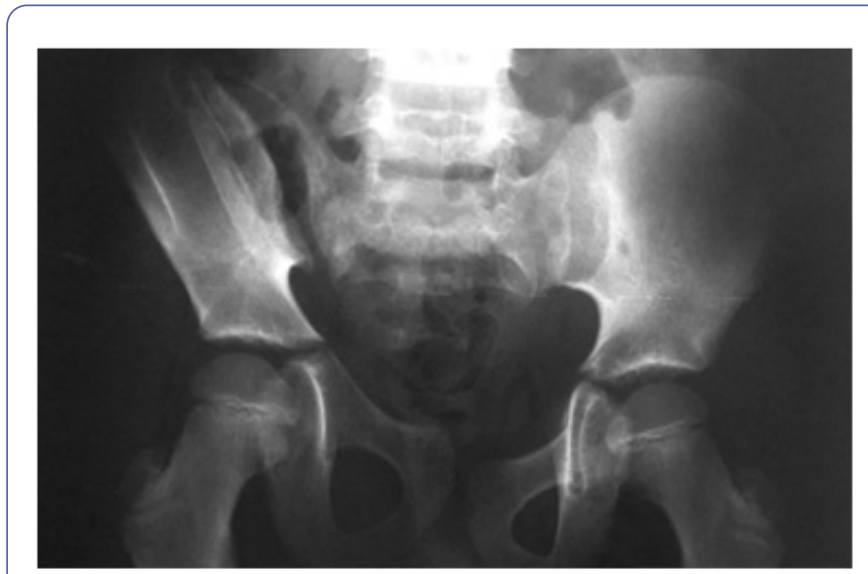

Figure 2: Type C2 pelvic fracture.

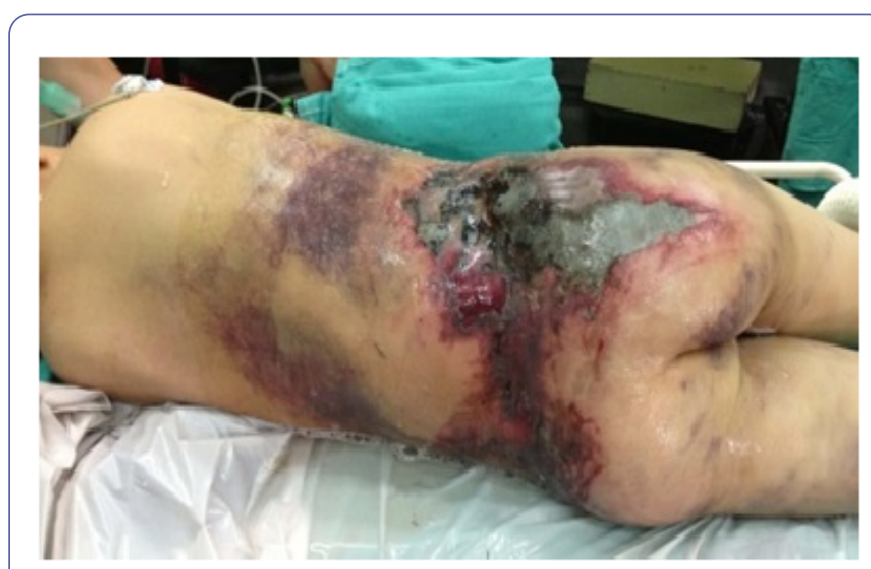

Figure 3: Skin injury.

\section{Treatment}

AO anterior pelvic stabilization with modular type supraacetabular splint with nails; Debridement of skin lesion after exposure of the right sacroiliac joint fracture; Stabilization of both sacroiliac joints with cannulated screws; Rotation of muscle flaps to cover exposed defects and 
placement of a free skin graft; Sealing of the recipient area with human amniotic membrane (Figures 4,5 and 6A-6C).

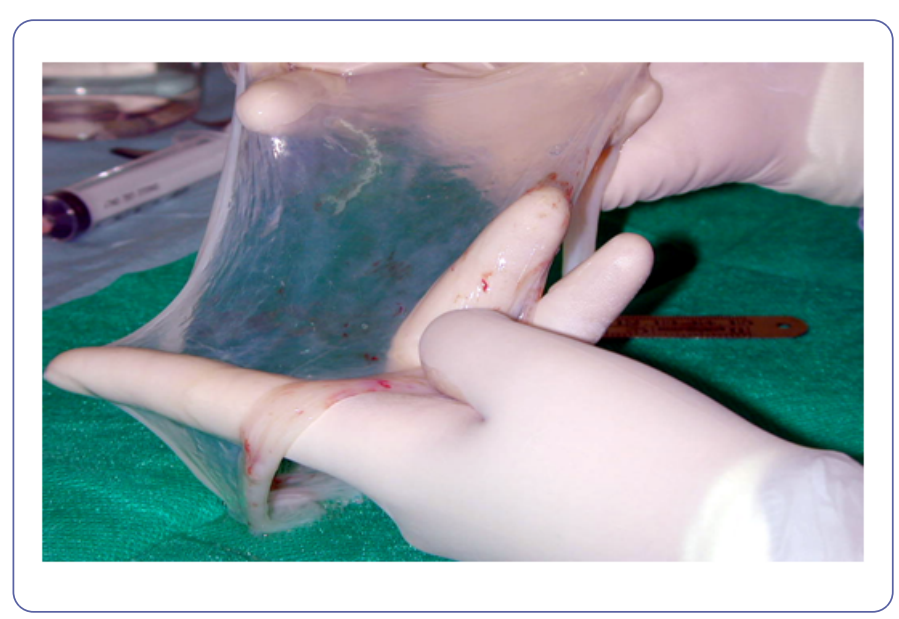

Figure 4: Amniotic membrane.
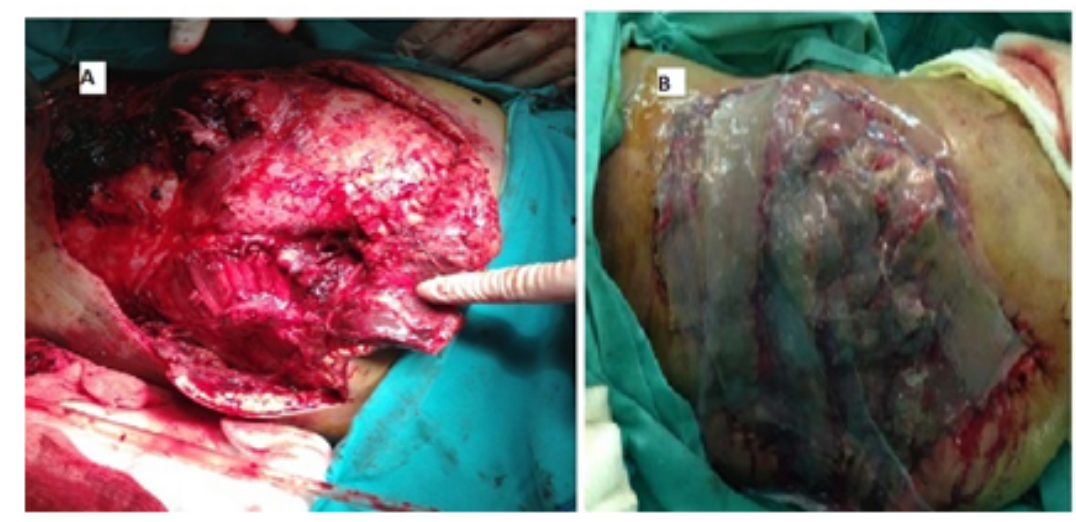

Figures 6A-6C: Treatment of exposure.

\section{Results}

The use of amniotic membrane allowed restoring the integrity of the skin by fixing the free flap in an anatomical location of difficult adherence.

\section{Conclusion}

Amniotic membrane is a highly [1] versatile tissue that is relatively cheap, easy to obtain and to use, process, and store. It is an excellent biological [2-4] dressing to promote healing of the skin in large and deep wounds. It promotes adhesion of the graft because of its tensile strength and induces reepithelialization through chemical mediators. It has antiinflammatory, antibacterial and antiviral properties [5] and functions as a scaffold in which cells can proliferate and
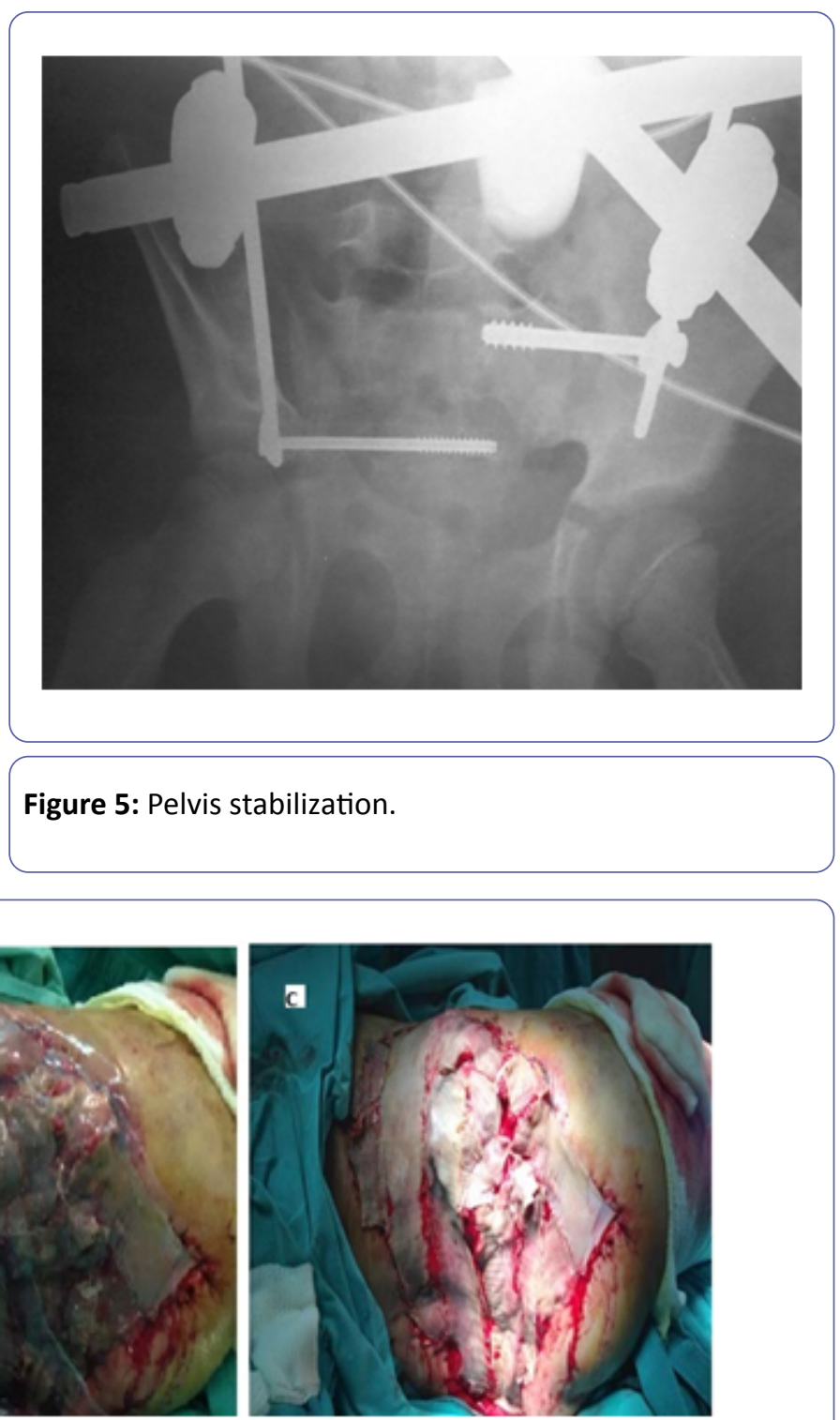

Figure 5: Pelvis stabilization.

differentiate as it has pluripotent cells among its layers. Amniotic membrane does not cause tumor effects.

\section{References}

1. Mamede AC, Carvalho MJ, Abrantes AM, Laranjo M, Maia CJ, et al. (2012) Amniotic membrane: from structure and functions to clinical applications. Cell Tissue Res 349: 447-458.

2. Insausti CL, Alcaraz A, García-Vizcaíno EM, Mrowiec A, LópezMartínez MC, et al. (2010) Amniotic membrane induces epithelialization in massive posttraumatic wounds. Wound Repair Regen 18: 368-77.

3. Gruss JS, Jirsch DW (1978) Human amniotic membrane: a versatile wound dressing. Can Med Assoc J 118: 1237-1246.

4. King AE, Paltoo A, Kelly RW, Sallenave JM, Bocking AD, et al. (2007) Expression of Natural Antimicrobials by Human Placenta and Fetal Membranes. Placenta 28: 161-169.

5. Hartstein B, Gausche-Hill M, Cancio LC (2013) Burn Injuries in Children and the Use of Biological Dressings. Pediatr Emerg Care 29: 939-948. 